\title{
Students' Perception on Teaching Practice Assessment: Implications on Teacher Professional Performance in Nigeria
}

Idayat Nike Balogun, Oladele

Department of Social Sciences Education, University of Ilorin, Nigeria, balogun.in@unilorin.edu.ng

\section{Jumoke Iyabode Oladele}

Department of Social Sciences Education, University of Ilorin, Nigeria, oladele.ji@ unilorin.edu.ng

\section{Zainab Omowunmi Jamiu}

Teaching practice is paramount in the training of student teachers as a form of exposure into the real world of Teaching. The study examined student teachers' perception on teaching practice assessment and its implications on professional practice. The population of the study was 1,393 university teacher trainees in 400 Level in a Nigerian university with a sample of 150 students using stratified random sampling technique. A researcher-designed questionnaire was used for data collection while data collected for this study were analyzed using percentage to answer research questions. he hypotheses were tested using t-test and ANOVA at 0.5 significance level. Findings of this study revealed that teaching practice exercise and Supervisors Assessment had a positive impact on student teachers. They differed in their perception on the impact of teaching practice based on the department but did not on the basis of gender. It was concluded from the findings that student teachers perceived teaching practice experience as being effective considering its positive impact on their professional training. It was therefore recommended among others that student teachers should be supervised by lecturers from departments other than their department in order to reduce familiarity during teaching practice assessment which sometimes affects their scores.

Keywords: student teachers, teaching practice (TP) assessment, professional performance, students' perception

\section{INTRODUCTION}

National development in Nigeria, and the world over, has been adjudged to be positively correlated to educational development. Teacher education occupies a central and foundational role in the educational system as well as the key to unlock all facets of development. Regardless of this fact, educational development may not be realizable without an effective and efficient teacher who is saddled with the responsibility of instilling knowledge in learners and guiding them as they engage in learning related activities. The training needs of a teacher become important as the quality of the teacher rests on the quality of the training acquired. Teacher education is a deliberate nurture of persons through training in order to impart knowledge, skills and values with the goal of passing on the acquired pedagogy to others. The revised National Policy on Education re-affirmed that teacher Education will continue to be given a major emphasis in all educational planning (Federal Government of Nigeria (FGN), 2013). This is so as no education system can rise above the quality of its teachers; and as such, teacher education program under any nomenclature should be given special attention.

Citation: Balogun, I. K., Oladele, J. I., \& Jamiu, Z. O. (2018). Students' Perception on Teaching Practice Assessment: Implications on Teacher Professional Performance in Nigeria. Anatolian Journal of Education, 3(2), 25-34. https://doi.org/10.29333/aje.2018.323a 
Jekayinfa (2000) present teacher education as a programme involving the upbringing of individuals through training in order to acquire knowledge, skills and values and transmit such to others and as such it is a cyclic affair in which both the content area and pedagogic skills are packaged for the trainees in order to prepare them to meet the requirement of the teaching profession. Thus, it is predicted that effective teaching is an intelligent, knowledge-based activity that takes proper account of teachers' professionalism. This understanding stems from the condition that teacher education and training is an embodiment of professional development (Ololube, 2007). Against this background are the objectives of teacher education as spelt out in the National Policy on Education (FGN, 2013), they are:

- $\quad$ to provide highly motivated, conscientious and efficient classroom teachers;

- $\quad$ to encourage further the spirit of inquiry and creativity in teachers;

- $\quad$ to help teachers to fit into the social life of the community and society at large;

- to produce teachers with the intellectual and professional background adequate for their assignment;

- $\quad$ to enhance teachers commitment to the teaching profession.

In assessing the achievement of these objectives, Afe (2002) observed that teacher education programmes have been deficient in providing teachers with intellectual and professional background adequate for their assignment in the society. It is therefore inevitable for teacher educators to focus on student teachers' pr-service training as teacher education becomes the main bane of the teaching profession in Nigeria. It nurtures prospective teachers and updates qualified teachers' knowledge and skills in the form of continuous professional development and therefore the need for standardized teacher education programs (Idowu, 2000). The implication of these submissions is that no educational system may rise above the quality of its teachers and as such; teacher education is the professional training that teachers receive for them to be classified as professionals. Teacher Education is that component of any educational system charged with the education and training of teachers to acquire the competencies and skills of teaching for the improvement in the quality of teachers for the school system (Afe, 1993).

The Nigerian University Commission (NUC) benchmark (2007) is in place to ensure that teacher trainees learn through rigorous professional development courses in education. They learn concepts in their subject areas and also learn strategies for teaching those subjects which are generally termed as teaching practice. As part of the package for students in the universities, teaching practice is often embarked on at specific periods of time during which teachers-in-training are posted to schools to teach in order to put to practice the knowledge and skills acquired during their training. Teaching practice embraces all the learning experiences of student teachers in schools (Akbar, 2000).

Evidence of behavioral changes as a result of student learning can be evaluated using teaching practices; having proved to be a relevant source of information about professional performance. This is because teacher assessment is typically firmly rooted in classroom observation, as most key aspects of teaching are displayed while teachers interact with their students in the classroom. As such, assessment of students on teaching practice is essentially an assessment of work-based learning which differs from assessing learning in academic context. There are some differences of opinion as to whether teaching meets the requirement of possessing a body of specialized knowledge. In teaching, both the subject matter knowledge and knowledge of education theory are essential to the preparation of teachers'. What is not appreciated is the fact that education differs from other professions in having the subject matter component, but in many ways, the theoretical knowledge needed by the teacher is the same as that needed by the doctor. It could, therefore, be said that teaching meets this particular criterion (Afe, 2006). Furthermore, Andabai (2013) states that during teaching practice, a student is supervised and evaluated not only by a supervisor allotted to him but also by a group of other lecturers who supervise him/her as a team; as well as a staff of the school in which he/she is teaching. The

Anatolian Journal of Education, October $2018 \bullet$ Vol.3, No.2 
supervision is usually carried out at least twice during each exercise. The students' performance is determined by finding the mean score of assessors' grades. Furthermore, an External Examiner conducts a random assessment of students on teaching practice and moderate internal assessors' grades (Jekayinfa, Yahaya, Yusuf, Ajidagba, Oniye, Oniyangi \& Ibraheem, 2012).

Each supervisor use different methods in assessing the student teachers after which they give their remarks to trainee teachers which serves as a feedback to the students after putting teaching into practice. While such remarks were an indication of how trainee teachers have progressed, Orland (2001) explained that the main intent of supervisors' remark is to help student teachers develop as competent teachers. Furthermore, since knowledge of the trainee teachers as reflected by the scores obtained during teaching practice assessment contributes significantly to student's certification and have implications on the quality of graduate teachers produced; it becomes necessary to know the student teachers' perception on teaching practice assessment and its implications on teachers professional performance in Nigeria and this constituted the main purpose of this study while providing answers to the following research questions as well as corresponding hypotheses one to four respectively:

i. What is the perception of student teachers on teaching practice exercise?

ii. What is the perception of student teachers on the impact of teaching practice exercise?

iii. What is the perception of student teachers on supervisors' assessment during teaching practice exercise?

iv. Is there any difference between male and female student teachers' perception on teaching practice exercise?

v. Is there any difference between male and female student teachers' perception ofn supervisors' assessment during teaching practice exercise?

vi. Is there any difference between student teachers' perception o impact teaching practice exercise based on department?

vii. Is there any difference between student teachers' perception on supervisors' assessment during teaching practice exercise based on the department?

H01: There is no significant difference in the student teachers' perception of the impact of teaching practice exercise on trainee teacher's professional performance based on gender.

H02: There is no significant difference in the student teachers' perception on supervisors' assessment during teaching practice exercise on trainee teacher's professional performance based on gender.

H03: There is no significant difference in the student teachers' perception on impact of teaching practice exercise on trainee teacher's professional performance based on department.

H04: There is no significant difference in the student teachers' perception on supervisors' assessment during teaching practice exercise on trainee teacher's professional performance base on department

\section{METHOD}

The design employed for this study is a descriptive survey type. Descriptive is concern with a description of events, attitude of people or the attitude of people towards the events and ideas as they are. This method enabled obtaining the opinion of a representative sample of the target population so as to infer the perspective of the entire population. This method is used because of its flexibility and effectiveness in information gathering in respect to this study. 
The population for this study is 1,393 training teachers in 400 Level from a Nigerian University for 2016/2017 academic session. This sample consisted of one hundred and fifty (150) student teacher selected from all the departments using the stratified random sampling technique; used to stratify students to various departments after which the respondents were randomly selected. The instrument that was used for data collection was questionnaire which was used to elicit information on the teaching practice assessment and its impacts on student teacher. The questionnaire is a closed-ended type in design. It was designed for student teachers only with a clear instruction. The questionnaire used comprises two sections A and B. Section A comprises of student teachers' demographic data such as matric number, level, sex, department while section B comprises of questions on the impact of teaching practice assessment on student teachers on a four-point Likert-scale type measuring scale (strongly Agreed: SA, Agree: A, Strongly Disagree: SD and Disagree: D) of which the respondent is expected to tick. The instrument was validated by measurement researchers who verified its validity in terms of content, grammar, items presentation and organization as well as the relevance of the items of the instrument. In other to determine the reliability of the instrument, it was trial tested on students from outside the faculty who will not be part of the sample used for the study. The reliability of the instrument was determined using the test-retest method of reliability and a reliability coefficient of 0.87 was obtained as the indicator of the reliability of the instrument. The descriptive and inferential statistical were be used to analyze the data collected for the study. Frequency count and percentage were used to analyze demographic data and research questions one to three while t-test was used to test the hypotheses one and two and ANOVA statistics to test hypotheses three and four. All the generated hypotheses were tested at 0.05 alpha levels.

\section{FINDINGS}

The validated instruments were administered to 150 teacher trainee from the Faculty of Education, and were all answered and returned at a rate of $100 \%$. The data collected for this study were analyzed and the results are presented in tables for easy interpretation. All the analyses were carried out using SPSS 20.

\section{Demographic Data}

Respondents were asked to indicate their gender as shown on table 1 .

Table 1

Distribution of respondents by gender

\begin{tabular}{lll}
\hline Gender & Frequency & Percentage $(\%)$ \\
\hline Female & 70 & 46.7 \\
Male & 80 & 53.3 \\
Total & 150 & 100 \\
\hline
\end{tabular}

Table 1 shows the frequency and percentage of male and female student teachers that participated in the study. Out of 150 respondents, $70(46.7 \%)$ female while $80(53.3 \%)$ of the respondents are males. This shows that the males' respondents were more than females' respondents.

Respondents were asked to indicate their departments as shown on table 2.

Table 2

Distribution of respondents by department

\begin{tabular}{lll}
\hline Department & Frequency & Percentage (\%) \\
\hline Arts Edu. (AED) & 14 & 9.3 \\
Adults \& Pry. Edu. (APE) & 8 & 5.3 \\
Counsellor Edu. (CED) & 14 & 9.3 \\
Edu Tech. (EDT) & 9 & 6.0 \\
Edu Mgt. (EMA) & 33 & 22 \\
\hline
\end{tabular}




\begin{tabular}{lll}
\hline Health Edu. (HED) & 25 & 16.7 \\
Human Kinetics (HKE) & 6 & 4.0 \\
Science Edu. (SED) & 10 & 6.7 \\
Social Science Edu. (SSE) & 31 & 20.7 \\
Total & 150 & 100.0 \\
\hline
\end{tabular}

The results in Table 2 indicate the frequency and percentage of respondents according to their departments. Out of 150 respondents, It could be concluded from Table 2 that out of nine departments, the Department of Educational Management are the majority while the least is from Department of Human Kinetics Education.

Research Question 1: What is the student teachers' perception on teaching practice exercise?

Table 3

Perception of student teachers on teaching practice exercise

\begin{tabular}{llllll}
\hline Item & SA $(\%)$ & $\mathrm{A}(\%)$ & $\mathrm{D}(\%)$ & $\mathrm{SD}(\%)$ & Remark \\
\hline Teaching practice engenders professionalism & $71(47.3)$ & $60(40.0)$ & $19(12.7)$ & $0(0.0)$ & High \\
TP experience is very useful & $87(58.0)$ & $60(40.0)$ & $2(1.3)$ & $1(0.7)$ & High \\
$\begin{array}{l}\text { TP is not necessary since I may not practice } \\
\text { teaching profession }\end{array}$ & $22(14.7)$ & $20(13.3)$ & $65(43.3)$ & $43(28.7)$ & Low \\
$\begin{array}{l}\text { TP oppourtunes putting to practice ideas and } \\
\text { theories }\end{array}$ & $65(43.3)$ & $78(52.0)$ & $5(3.3)$ & $2(1.3)$ & High \\
TP is an interesting experience & $52(34.7)$ & $74(49.3)$ & $18(12.0)$ & $6(4.0)$ & High \\
TP an important aspect of teacher education & $89(59.3)$ & $53(35.3)$ & $2(1.3)$ & $6(4.0)$ & High \\
\hline
\end{tabular}

Table 3 shows the student teachers' perception on the teaching practice programme in Nigeria was high on teaching practice engendering professionalism, the experience being very useful, the opportunity for putting ideas and theories to practice, it being an interesting experience and an important aspect of teacher education with a percentage agreement of $87.3 \%, 98 \%, 95.3 \%, 84.0 \%$ and $94.6 \%$ respectively. Also, student teachers' perception on the teaching practice programme in Nigeria was low on teaching practice not being necessary since they may not practice teaching profession with a percentage disagreement of $72 \%$.

Research Question 2: What is the student teachers' perception on impact of teaching practice exercise on trainee teacher's professional performance?

Table 4

Perception of student teachers on the impact of teaching practice exercise on trainee teacher's professional performance

\begin{tabular}{llllll}
\hline Item & SA (\%) & A (\%) & D (\%) & SD (\%) & Remark \\
\hline $\begin{array}{l}\text { TP helps to decide to take teaching as a } \\
\text { profession }\end{array}$ & $57(38.0)$ & $69(46.0)$ & $21(14.0)$ & $3(2.0)$ & High \\
$\begin{array}{l}\text { TP helps to learn plan, prepare and present } \\
\text { lessons }\end{array}$ & $88(58.7)$ & $53(35.3)$ & $9(6.0)$ & $0(0.0)$ & High \\
$\begin{array}{l}\text { TP gives exposure to the problems and } \\
\text { prospects of the profession }\end{array}$ & $81(54.0)$ & $61(40.7)$ & $7(4.7)$ & $1(0.7)$ & High \\
$\begin{array}{l}\text { TP broadens knowledge of subject matter } \\
\text { TP aids professionalism }\end{array}$ & $63(42.0)$ & $70(46.7)$ & $14(9.3)$ & $3(2.0)$ & High \\
\hline
\end{tabular}

Table 4 shows the student teachers' perception on the impact of teaching practice exercise. It was observed that the perception of student teachers on the impact of teaching practice exercise on trainee teacher's professional performance was high on teaching practice being helpful in deciding to take teaching as a profession 126(84\%), planning, preparing and presenting lessons 141(94\%), exposing trainee teachers to the problems and prospects of the teaching profession 142(94.7\%), broadening 
knowledge of subject matter 133(82.7\%) and engendering professionalism 134(89.3\%). This show that teaching practice exercise impacted on trainee teacher's professional performance the a

Research Question 3: What is the perception of student teachers on supervisors' assessment during teaching practice exercise?

Table 5

Perception of student teachers on supervisors' assessment during teaching practice programme

\begin{tabular}{|c|c|c|c|c|c|}
\hline Item & $\mathrm{SA}(\%)$ & $\mathrm{A}(\%)$ & $\mathrm{D}(\%)$ & $\mathrm{SD}(\%)$ & Remark \\
\hline $\begin{array}{l}\text { Supervisors use same methods for } \\
\text { assessment }\end{array}$ & $31(20.7)$ & $58(38.7)$ & $45(30.0)$ & $16(10.7)$ & High \\
\hline $\begin{array}{l}\text { Supervisors attitude makes TP a worthwhile } \\
\text { experience }\end{array}$ & $30(20.0)$ & $73(48.7)$ & $37(24.7)$ & $10(6.6)$ & High \\
\hline $\begin{array}{l}\text { Supervisors assessment brings out students } \\
\text { professional skills }\end{array}$ & $20(13.3)$ & $37(24.7)$ & $43(28.7)$ & $50(33.3)$ & Low \\
\hline $\begin{array}{l}\text { Students are comfortable being assessed } \\
\text { while teaching }\end{array}$ & $39(26.0)$ & $75(50.0)$ & $27(18.0)$ & $9(6.0)$ & High \\
\hline Assessment aids teaching effectively & $51(34.0)$ & $75(50.0)$ & $16(10.7)$ & $8(5.3)$ & High \\
\hline $\begin{array}{l}\text { Assessment aids the development of } \\
\text { classroom management skills }\end{array}$ & $52(34.7)$ & $78(52.0)$ & $15(10.0)$ & $5(3.3)$ & High \\
\hline $\begin{array}{l}\text { Assessment aids the use of instructional } \\
\text { materials }\end{array}$ & $66(44.0)$ & $68(45.3)$ & $13(8.7)$ & $3(2.0)$ & High \\
\hline $\begin{array}{l}\text { Assessment aids student engagement during } \\
\text { teaching }\end{array}$ & $54(36.0)$ & $75(50.0)$ & $15(10.0)$ & $6(4.0)$ & High \\
\hline Assessment boasts trainee's confidence & $78(52.0)$ & $55(36.7)$ & $10(6.7)$ & $7(4.7)$ & High \\
\hline
\end{tabular}

The results in Table 5 shows the student teachers' perception on supervisors' assessment during teaching practice exercise. It was observed that student teachers' perception with a percentage agreement of $89(59.4 \%)$ on supervisors using same methods for assessment, 103(68.7\%) on supervisors attitude making TP a worthwhile experience, 114(76\%) on students being comfortable assessed while teaching, 126(84\%) on assessment aiding effective teaching, 140(86.7\%) on assessment aiding the development of classroom management skills, 134(89.3\%) on assessment aiding the use of instructional materials $129(86.0 \%)$ on assessment aiding student engagement during teaching and $133(88.7 \%)$ on assessment boasting trainee's confidence. However, their perception on supervisors assessment bringing out students professional skills was low with a percentage disagreement of 93(62.0\%). This showed that student teachers perceived that supervisors' assessment had a positive impact on their being professional teachers.

\section{Hypotheses Testing}

All the research hypotheses formulated are tested at alpha $=0.05$. The research hypothesis would be rejected if the calculated significant level is less than 0.05 while it will not be rejected if it is greater than 0.05 .

$\mathbf{H}_{01}$ : There is no significant difference in the student teachers' perception on the impact of teaching practice exercise on trainee teacher's professional performance based on gender. 
Table 7

t-test analysis of male and female student teachers' perception on the impact of teaching practice exercise on trainee teacher's professional performance

\begin{tabular}{llllllll}
\hline Gender & No & Mean & Std. & T & Df & Sig. (2-tailed) & Decision \\
\hline Male & 80 & 16.51 & 2.31 & -1.161 & 148 & 0.247 & Do not reject \\
Female & 70 & 16.91 & 1.89 & & & & \\
\hline
\end{tabular}

The results in Table 7 show that the calculated significant level is 0.247 which is greater than the alpha level of 0.05 , therefore, hypothesis one is not rejected. This means that male and female student teachers do not differ in their perception of the impact of teaching practice programme

$\mathbf{H}_{\mathbf{0 2}}$ : There is no significant difference in the student teachers' perception of supervisors' assessment during teaching practice exercise on trainee teacher's professional performance based on gender.

Table 8

t-test analysis of male and female student teachers' perception of supervisors' assessment during teaching practice exercise

\begin{tabular}{|c|c|c|c|c|c|c|c|}
\hline Gender & No & Mean & Std. & $\mathrm{T}$ & $\mathrm{df}$ & Sig. (2-tailed) & Decision \\
\hline \multirow[t]{2}{*}{ Male } & 80 & 26.56 & 4.34 & & & & \\
\hline & & & & -0.526 & 148 & 0.600 & Do not reject \\
\hline Female & 70 & 26.94 & 4.49 & & & & \\
\hline
\end{tabular}

The results in Table 8 show that the calculated significant level is 0.600 which is greater than the alpha level of 0.05 , therefore, hypothesis two is not rejected. This means that male and female student teachers do not differ in their perception on supervisors' assessment during teaching practice programme in the University of Ilorin, Ilorin, Nigeria.

$\mathbf{H}_{\mathbf{0 3}}$ : There is no significant difference in the student teachers' perception on the impact of teaching practice exercise on trainee teacher's professional performance based on department.

Table 10

ANOVA analysis of student teachers' perception of impact teaching practice exercise base on the department

\begin{tabular}{lllllll}
\hline Source & Sum of Squares & Df & Mean Square & F & Sig. & Decision \\
\hline Between Groups & 92.944 & 8 & 11.618 & 2.91 & 0.005 & Reject \\
Within Groups & 562.850 & 141 & 3.992 & 0 & & \\
Total & 655.793 & 149 & & & & \\
\hline
\end{tabular}

Table 10 shows that the calculated significant level is 0.005 which is less than the alpha level of 0.05 , therefore, hypothesis three is rejected. This means that student teachers differ in their perception on impact teaching practice programme base on the department.

$\mathbf{H}_{\mathbf{0 4}}$ : There is no significant difference in the student teachers' perception of supervisors' assessment during teaching practice exercise on trainee teacher's professional performance base on the department 
Table 11

ANOVA analysis of student teachers' perception of supervisors' assessment during teaching practice exercise base on the department

\begin{tabular}{lllllll}
\hline & Sum of Squares & Df & Mean Square & F & Sig. & Decision \\
\hline Between Groups & 513.057 & 8 & 64.132 & 3.79 & \multirow{2}{*}{0.000} & \multirow{2}{*}{ Reject } \\
$\begin{array}{l}\text { Within Groups } \\
\text { Total }\end{array}$ & 2348.303 & 141 & 16.910 & 3 & & \\
\hline
\end{tabular}

Table 11 shows that the calculated significant level is 0.000 which is less than the alpha level of 0.05 , therefore, hypothesis four is rejected. This means that student teachers differ in their perception of supervisors' assessment during teaching practice programme base on the department.

\section{CONCLUSION, DISCUSSION, AND SUGGESTION}

It could be deduced from the findings of this study that student teachers perceived teaching practice experience as being good and that it had a positive impact on their professional training as teachers to be. Both male and female perceived the experience and impact the programme had on them the same but differ in their perception based on department. It could also be concluded that male and female perceived supervisors' assessment the same but differ in their perception based on department.

The findings of the study revealed that all pre-service teachers emphasized the usefulness of experiences and skill acquired from teaching practice exercise as they had the opportunity to practice teaching in a real-life situation. This finding is also in line with Ramganesh (2011), who said that teaching practice provides the trainees with an opportunity to acquire practical skills through direct experience. The finding of this study is also in line with Andabai (2013), assertion that practice teaching occupies a key position in the programme of teacher education as it culminates experience in teacher preparation while providing an ample chance to apply theories and practice of education they have been taught in a real-life situation.

The finding on the impact of teaching practice showed that teaching practice exercise had a positive impact on student teachers as perceived by more than $80 \%$ of the respondents. This is in line with Vogel and Harendza (2016) who assertion that during the period of teaching practice, student-teachers are provided with the opportunity to engage in profitable experiences under the guidance and supervision of professional supervisors and the regular teachers of the cooperating schools. The merit in this practice is that the training student-teachers are exposed to during teaching practice provide them with a good learning opportunity for basic practical skills.

The findings of this study also revealed that there is no difference in perceptions of both male and female student teachers on the impact teaching practice programme has on them. The reason for this may not far fetch as both male and female student teachers are exposed to the programme in the same way and are supervised by the same supervisors. Since, students are not separated based on gender; therefore, their perception about the impact of teaching practice programme may not differ. It was also discovered from the findings that male and female student teachers' opinions of supervisors' assessment during teaching practice programme in the University of Ilorin, Ilorin did not differ. This is also true as assessment by the supervisors is meant for all the students irrespective of their gender. This also means that the supervisors are not gendered biased as they treat the students equally.

The findings also revealed that student teachers' perception on the impact of teaching practice programme differs on the bases of their departments. This means that student teachers base on the department they belong, did not view the impact the programme has on them the same way. The reason for this may be due to the fact that though the students are in the same faculty they were taught and examined by lecturers from their departments. This finding support Gantt and Darey, (1973) view 
that behaviour of student-teachers changes due to changes in the environment. It was also discovered from the findings of this study that student teacher's perception of the supervisors' assessment differs based on their department. This means that student teachers from different departments did not perceive the supervisors' assessment in the same way. So their views were influenced by the department they belong. The reason for this difference may be connected with the fact that majority of the students were supervised by lecturers from their departments.

The following are therefore suggested based on the study:

1. Student teachers should be supervised by lecturers from a department other than their department in order to reduce familiarity during teaching practice assessment which sometimes would affect their scores;

2. There should be a conference between the Supervisors and student teachers after the assessment so as to exchange verbal feedback so that student teachers can improve on their area of strength and correct their area of weaknesses;

3. Student teachers should master their lesson topics and lesson so as to prepare ahead of time to avoid memorization of lesson topics only when supervisors come around to assess them;

4. Supervisors should also act more as a learner by bringing himself or herself to the level of the students in the class and participate in the teaching-learning so that supervisee can be able to perform optimally according to his or her ability. Thereby, the supervisor can make an appropriate correction objectively.

5. It should be included in the orientation of the teaching practice exercise that, student teacher should not take teaching practice exercise as acting of the film which makes them engaged in rehearsal prior to the arrival of supervisor which lead to failure, panic, and anxiety when they did not meet what expected from a supervisor. But be taking very seriously as to demonstrate wholeheartedly what they have acquired theoretically in their years of receiving training as teachers to be.

\section{REFERENCES}

Afe, J.O. (2002). Designing Curriculum, Instruction, Assessment, and Professional Development in Learning and Understanding (Chapter: 7) In Jerry P. Gollub, Meryl W. Bertenthal, Jay B. Labov, and Philip C. Curtis (Eds.), Learning and Understanding: Improving Advanced Study of Mathematics and Science in U.S. High Schools. Washington, DC: National Academy Press.

Afe, J.O. (2006). Reflections on Becoming a Teacher and the Challenges of Teacher Education. University of Benin: Inaugural Lecture Series 64.

Ramganesh, E. (2011). Chapter 1: introduction and conceptual frame work- Shodhganga. http://shodhganga.inflibnet.ac.in/bitstream/10603/40285/2/chapter1.pdf

Akbar, R. A. (2002). A study of Practice Teaching of Prospective Secondary School Teachers and Development of a Practice Teaching Model. Arid Agricultural University, Rawalpindi: An unpublished Ph.D. Thesis.

Andabai, P.W. (2013). The Impact of Teaching Practice on Trainee Teachers in the Nigerian Tertiary Institutions: The Niger Delta University Experience. Academic Journal of Interdisciplinary Studies, 2 (5), 109 - 115. doi:10.5901/ajis.2012.v2n5p109.

Federal Government of Nigeria (FGN) (2013). National policy on education. NERDC Press: YabaLagos. 
Gantt, N.W. \& Darey, B. (1973). Re-student Teachers Treat to Field-supplemented Method Courses. Washington D.C.; Association of Supervision and Curriculum Development.

Idowu, A. I. (2000). Evaluating the student teacher. In Idowu, A.I., Daramola, S. O., Olorundare, A. S., Obiyemi, O. O., Ijaiya, N. Y. S., \& Lafinhan, K. (Eds.), A guide to teaching the practice. Ilorin: Hayter.

Jekayinfa, A.A. (2000). The essence of lesson presentation in teaching practice. In A.I.Idowu, S.O. Daramola, A.S. Olorundare, O.O. Obiyemi, NYS. Ijaiya, and K. Lafinhan (Ed.). A guide to teaching practice.Ilorin: Faculty of Education, University of Ilorin

Jekayinfa, A.A., Yahaya, L.A., Yusuf, A., Ajidagba, U.A., Oniye A.O., Oniyangi, S.O. \& Ibraheem, T.O. (2012). Lecturers' assessment of teaching practice exercise in Nigerian universities. Journal of Education and practice, 3(4), 79-86. Retrieved from http://www.iiste.org/journals

National University Commission (NUC) (2007). Benchmark Minimum Academic Standards for for Undergraduate Programmes in Nigerian Universities (Education). Abuja: NUC.

Ololube, N.P. (2007). The relationship between funding, ICT, selection processes, administration and planning and the standard of science teacher education in Nigeria. Asia-Pacific Forum on Science Learning and Teaching, 8(1), Article 4.

Orland, L. (2001). Learning to Mentor as learning a second Language of Teaching. Cambridge Journal of Education, 33(1), 53-68.

Vogel, D. \& Harendza, S. (2016). Basic practical skills teaching and learning in undergraduate medical education: a review on methodological evidence. GMS Journal for Medical Education 2016, 33(4), 1-19. 